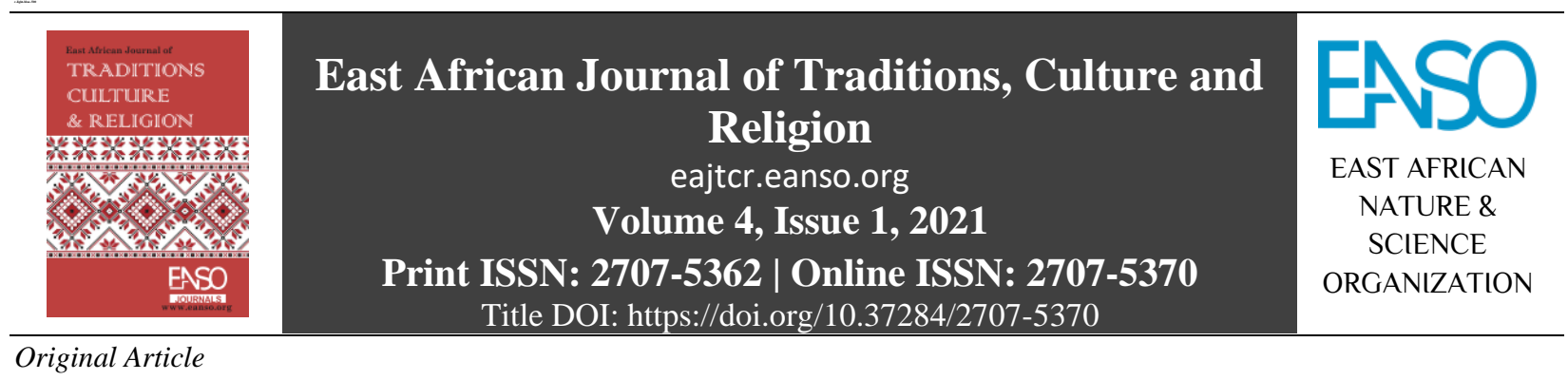

\title{
Exploring Human Sexuality of the Single Adult in the Church Today: A Reflection of Single Women.
}

\author{
Nehemiah Nyaundi, $T h D^{1^{*}}$ \\ ${ }^{1}$ Professor of Religion at the Department of Theology and Religious Studies of the University of Eastern Africa P. O. Box 2500- \\ 30100, Eldoret, Kenya. \\ *Author for Correspondence Email: nenyaundi@ueab.ac.ke
}

Article DOI: https://doi.org/10.37284/eajtcr.4.1.560

\section{Date Published: ABSTRACT}

08 November 2021 The family is an institution on which a nation is built. Where there are strong family structures, there are strong nations. This paper deals with a social sift

Keywords: whereby more and more adults are choosing not to marry and keep families but instead are opting to remain single. The discussion in this paper alleges

Human Sexuality,

Singlehood, Single Adults,

Church, that the needs of the single man or woman in the church are not taken care of. Consider for instance, that church programmes cater for the needs of children very well. The needs of the youth are meticulously catered for. Married people are served in elaborate family-life programmes and in a similar version, widows are provided for by religious and economic empowerment African Perspective, associations. But when it comes to the needs of the single adult, no provision Single Women. is made to address exceptional needs such as management of sexual needs within that category. Bible writers specifically address other categories in the church, not so the single adult, man or woman. The church teaches the single adult to keep one's sexual drive under wraps until marriage. The teaching regulates engagement in sex before marriage and out of marriage assuming that the person will eventually marry. This paper emphasizes the impact singlehood is posing to the people in the church including the life of the church today.

\section{APA CITATION}

Nyaundi, N. (2021). Exploring Human Sexuality of the Single Adult in the Church Today: A Reflection of Single Women. East African Journal of Traditions, Culture and Religion, 4(1), 27-35. https://doi.org/10.37284/eajtcr.4.1.560

\section{CHICAGO CITATION}

Nyaundi, Nehemiah. 2021. "Exploring Human Sexuality of the Single Adult in the Church Today: A Reflection of Single Women". East African Journal of Traditions, Culture and Religion 4 (1), 27-35. https://doi.org/10.37284/eajtcr.4.1.560.

\section{HARVARD CITATION}

Nyaundi, N. (2021) "Exploring Human Sexuality of the Single Adult in the Church Today: A Reflection of Single Women", East African Journal of Traditions, Culture and Religion, 4(1), pp. 27-35. doi: 10.37284/eajtcr.4.1.560.

27 | This work is licensed under a Creative Commons Attribution 4.0 International License. 
IEEE CITATION

N. Nyaundi, "Exploring Human Sexuality of the Single Adult in the Church Today: A Reflection of Single Women", EAJTCR, vol. 4, no. 1, pp. 27-35, Nov. 2021.

\section{MLA CITATION}

Nyaundi, Nehemiah. "Exploring Human Sexuality of the Single Adult in the Church Today: A Reflection of Single Women". East African Journal of Traditions, Culture and Religion, Vol. 4, no. 1, Nov. 2021, pp. 27-35, doi:10.37284/eajtcr.4.1.560.

\section{INTRODUCTION}

The discussion in this paper alleges that the needs of the single man or woman in the church are not taken care of. Consider for instance, that church programmes cater for the needs of children very well. The needs of the youth are meticulously catered for. Married people are served in elaborate family-life programmes and in a similar version, widows are provided for by religious and economic empowerment associations. But when it comes to the needs of the single adult, no provision is made to address exceptional needs such as management of sexual needs within that category. Bible writers specifically address other categories in the church, not so the single adult, man or woman. The church teaches the single adult to keep one's sexual drive under wraps until marriage. The teaching regulates engagement in sex before marriage and out of marriage assuming that the person will eventually marry.

Evidently, the church is reluctant to adjust its position concerning sexual behaviour among unmarried adults. During the last many years, modernistic sex-related behaviour has been brought to the fore for discussion. In some church organizations, people who are involved in exceptional sexual behaviour are increasingly getting accepted; so-called LGBTQ+ are nowadays getting incorporated into various associations of the church with little prompting.

The question that remains mulls over the issue of the single female adult's possibility to occupy a

\footnotetext{
1 Many church organizations do not ordain women citing various reasons for not doing so. See Russell L. Staples. "A Theological Understanding of Ordination." In Nancy Vhymeister ed. Women in Ministry: Biblical and Historical Perspectives. Berrien Springs MI Andrews University Press, 1998.

2 There are many books which have this history. See Bengt Sundkler and David Steed. A History of the Church in Africa. Cambridge University Press, 2000.
}

position in the leadership of the church. What role could a single female adult be allowed to play in the church? Could she be allowed to play a role in any case? Some Christian organizations have embraced women into key areas of organizational leadership positions all the way up to the office of bishop, while others are still lethargic about the issue. There are other organizations that allow women into limited leadership roles but deny them the right to ordination, ${ }^{1}$ thereby effectively excluding women from eligibility to officiate in key liturgical functions of the church.

\section{SINGLE AND UNATTACHED WOMEN IN THE CHURCH}

The Christian teaching as a religious perspective has been continuously taught in Africa for well over two hundred years. ${ }^{2}$ I say this well aware that Christianity has been viewed as a native of Africa since its inception in the first century after the death and the resurrection of Jesus Christ. ${ }^{3}$ After about four centuries of vigorous Christian presence in Africa North of the Sahara Desert, Christianity lost its grip and had to be re-introduced as if fresh during the so-called Era of Missions, a period starting approximately from the year $1800 .{ }^{4}$ When the time of the re-introduction came, the focus was on Tropical Africa.

Even if Christianity has been taught in Tropical Africa for several centuries, it can correctly be said that the religion is not indigenous but a newcomer to Africa. When Christianity was introduced to the African man and woman by European, American

\footnotetext{
${ }^{3}$ Edwin W. Smith. The Christian Mission in Africa. London: International Missionary Council, 1926.

${ }^{4}$ See Richard Gray. 'Problems of Historical Perspective: The Planting of Christianity in Africa in the $19^{\text {th }}$ and $20^{\text {th }}$ Centuries,' In C.G. Baeta ed. Christianity in Tropical Africa. Oxford: Oxford University Press, 1968, p.18-33.
} 
and Canadian missionaries, the African convert to Christianity was taught the beliefs and practices of the new religion, which differed significantly from the indigenous African religious beliefs and practices. To this day, there are many areas of difference between African traditional religion and Christianity. One distinguished area of difference is found in the practice of human sexuality; how sexuality should be understood, enjoyed and practised by the African convert to Christianity.

In 2005 I published a paper in a book whose theme surveyed challenges that were conceived to be confronting the life of the Christian church in Africa at the time. ${ }^{5}$ The paper singled out the institution of the family and examined how it had undergone change using the investigative tool known as the rapid social change theory. At the time, I stated that the challenges were not new par se, but that they were going to be experienced in a new way. What stood out as critical challenges fifteen years ago are similar to what are posing challenges today. I could as well say much the same thing in this paper also. The paper examined how the family was changing at the time but did not foresee singlehood as an aggressive challenge that it is today.

The family is an institution on which a nation is built. Where there are strong family structures, there are strong nations. This paper deals with a social sift whereby more and more adults are choosing not to marry and keep families but instead are opting to remain single. Of course, I acknowledge that there are people who are single without their choice. I have not been able to evaluate the percentages of those single by choice and those who are single without their choice. This paper emphasizes the impact singlehood is posing to the people in the church including the life of the church today.

The purpose of this discussion is to explore how the human sexuality needs of the single adult impact the lives of fellow church members in the congregation. The scenario under consideration is encapsulated in the life and times of Kemunto, a single female adult

\footnotetext{
5 See Nehemiah M. Nyaundi 'The Contemporary African Family in Light of Rapid Social Change Theory' in Nahashon W. Ndun'gu and Philomena N. Mwaura eds. Challenges and Prospects of the Church in Africa: Theological Reflections of
}

who provides a typical example of what goes on in society today.

Kemunto is a young woman aged 27 years. She lives at Magenche Market, a small shopping centre located at the border between two County jurisdictions. On either side of the border live two different ethnic groups, something that makes the market to be a vibrant hub of all sorts of activities. Kemunto became pregnant while in Form Three out of a relationship she had with a classmate. She dropped out of school because of the pregnancy. Kemunto's parents did not bother to send her back to school after she gave birth. A year after her son was born, Kemunto cohabited with a man who sired two children with her. Her four-year marital relationship ended in failure. This is how Kemunto found herself living in a rented room at the back of one of the shops at Magenche.

At the moment, Kemunto leads a difficult life at the shopping centre. She ekes a living by doing menial tasks to support herself and her three children. She washes people's clothes, cleans private homes, harvests tea leaves, cultivates maize fields, among other household chores. Sometimes Kemunto fails to find work for days in a row. When such times come, she offers her company to both young and old men in exchange for money. Kemunto has lived this way for many years considering that she is now approaching forty years of age. Kemunto's single and unattached status impacts the sexual behaviour of men in the society where she lives. Whenever it is convenient, Kemunto participates in communal activities including attendance in one of the local churches.

\section{Impact of Singlehood on the Church Polity}

There are many single women in the church. They are single because they have never been married, were married at one time but are now separated, divorced, widowed or that they have decided not to get married. What is categorical to state is that there are many categories of 'single' women in the church. The question which does not have a categorical answer is: do the single women have any

the $21^{\text {st }}$ Century. Nairobi: Paulines Publications Africa, 2005: 71-87.

29 | This work is licensed under a Creative Commons Attribution 4.0 International License. 
impact on the married lives of fellow church members? This question is based on the premise that the single women are sexually normal and therefore active so that they obviously experience the urge to enjoy their sexuality. At a second level, one may ask; how do these single women get their sexual needs taken care of?

The single woman is supposedly an active member of the church and is sexually active as well. One can speculate that the single woman gets her sexual needs taken care of by the men in the church and also from the wider society. Where it may be the case that the men of the church are the ones who fulfil the sexual desires of the single women in the church, then we are imagining the worst-case scenario; namely that the single women actually impact the church including what goes on in the lives of the men of the church. By talking of the men of the church, we mean those in the pews and also the (clergy?) commonly referred to as the "men of the cloth.' Cases where the men of the cloth have been found to have unholy liaisons with the women of the church both single and attached are especially not lacking. The media both print and audio are awash with these kinds of scandalous associations. ${ }^{6}$

Often, there is the unattached economically well-off woman and the economically impoverished one. Both types of women are perceived as a threat to the married woman in the church. Married women dread the single woman in the church, perceiving her as a potential tempter of their husbands. In a scenario where the single woman is needy, the case is even more complicated. To begin with there are some men who fear to assist the single woman financially because they suppose that they could be misunderstood as having some liaison with the woman. It is also imaginable that after a man has assisted a single woman that she starts to feel indebted to the man and may thereafter start to behave in a manner whose body language may send

\footnotetext{
6 See for example: “Killer Pastor's suicide note lays bare his frustrations in 13-year marriage' in Daily Nation Wednesday January 8, 2020 p. 22. On January 5, 2020 a pastor of Ground for God's Gospel Ministries in Mombasa stabbed his wife to death in the church over a quarrel involving leadership and marital disputes.

${ }^{7}$ While I was going through the motions of this article, I talked to a married woman who opined that what most men do not know is that unattached women view any man who seduces her
}

an amorous message to the man. Further, it is not farfetched to guess that a man may offer assistance to a single woman with strings attached. What is straightforward to say is that single women in the church are vulnerable. There are men in the church who take advantage of that vulnerability as well as there are women who exploit that status to get their needs fulfilled.

\section{Views about Sexuality in the Bible}

The Bible speaks frankly about human sexuality as a matter of course, acknowledging that sexuality is an inherent component of humanness. There are many passages where the matter of sexuality is recounted freely and candidly. ${ }^{8}$ A flagship text about the matter of singlehood in relation to sexuality is found in Paul's letter to the Corinthian church:

Now for the matters you wrote: "It is good for a man not to have sexual relations with a woman." But since sexual immorality is occurring, each man should have sexual relations with his own wife, and each woman with her own husband (1 Corinthians 7:1-2).

In this text, Paul addresses the subject of sexuality explicitly. The Corinthians had apparently written to Paul inquiring about how to deal with sexuality and singlehood. Paul replies that to be single is a gift from God which he himself was benefiting from. He proceeds to inform them that not everyone could endure singlehood, advising that marriage was the better option rather than singlehood. Paul states categorically that sexual drive is a strong emotion, to the extent that it may 'burn' the individual who cannot handle abstention.

In the letter to his apprentice Timothy, Paul recognized the strength of the sexual drive when he advised that younger widows should not be enlisted among those to be assisted because being young,

as a 'provider.' This is probably how it is said that some single women have a man who pays her rent and another who does her shopping.

${ }^{8}$ Both the Old and the New Testaments have record of sexual relations stated openly. 
they probably would like to get married. 'As for the younger widows, do not put them on such a list. For when their sensual desires overcome their dedication to Christ, they want to marry' (1 Timothy 5:11). According to Paul, singlehood is not a bad thing, but one has to be specially endowed in order to be able to endure being single. Notice that the argument concerning singlehood and dedication is the reason why some religious organizations promote singlehood in religious service.

The Bible specifies what is to be considered an appropriate relationship between the male and female genders. In the book of Genesis, God states the roles of the genders with the matter of sexuality implicitly assumed. Critics of the Bible think that Christian teaching is anti-sex, even speculating that the sin of Adam and Eve involved sex. This view is erroneous. The correct view is that God created sex including regulating the boundaries within which sex should occur. ${ }^{9}$ The poems found in the book Song of Songs 7:6-14 are about romance, passion, desire and attraction to beauty and physical elegance of the opposite sex as a source of joy and pleasure.

What however is correct to say is that what the Bible says concerning sexuality is not exhaustive in the sense that it does not cater for the entirety of the needs of the contemporary Christian. Critical issues such as sex for pleasure, masturbation, abortion, same-gender sex, use of contraceptives, et cetera are not articulated in a manner that resonates with the living experience of the contemporary Christian, old or young. Over the last decade or so, the amorphous group which wishes to be categorized as LGBTQ (Lesbians, Gays, Bisexual, Transgender, and Queers) ${ }^{10}$ is aggressively pushing to be accorded social recognition and equal rights similar to those accorded to the rest of society.

In the Genesis story of creation, God created all animals in pairs. After the creation of Adam, God saw that it was not good for Adam to be alone leading to the creation of Eve as a companion suitable to Adam (Gen 2:18). When Noah took animals into the ark, he did so in pairs (Gen 6:19).

\footnotetext{
9 See Wilfred R. Kent. God Created Sex. Today's World Ministries, 2011.

${ }^{10}$ The acronym stands for Lesbian, Gay, Bisexual, Transgender, Questioning, 'Plus.' It is regarded as representative of diverse
}

This is to say that for humanity to be complete, a union of a man and woman is imperative. This reality argues strongly against the phenomenon of singlehood which is a growing trend in the church today.

After creation, humanity was tasked to be 'fruitful and multiply' (Gen 1:28). Hence the specification ' $a$ man shall leave his father and mother and cling to his wife and they become one flesh' (Gen 2:24). This implies that a man is not complete alone, neither is a woman. Other than the theological meaning that may be extracted out of the text in John paper eight concerning the woman caught up in adultery, one wonders whether there was another reason why Jesus refused to condemn the woman. ${ }^{11}$

\section{Contours of Human Sexuality}

Contemporary society is increasingly getting defined by sex, considering that the allure to think about sex including the fact that sexual stuffs are displayed for sale on open shelves at the shopping malls. On the way to work in the morning more often than not, the talk shows and music blaring from $\mathrm{FM}$ radios that blast in public transport vehicles contain explicit messages about sex. The same is the case on the way back from work. As if that is not enough, at home after work, the intrusive television commercial advertisements unambiguously drive the viewer's imagination to sex and sexual innuendos. We live in a sex-saturated society. It is considered 'cool' to appear sexy. Sex is used as an attraction to sell a car, a house, a skirt, a suit, etc. To advertise a new airline, the photograph of a beautiful model is used to attract travellers. To advertise a new tourist resort, a beautiful young woman often half-naked is used to invite tourists to come to the resort, et cetera.

'Human sexuality' is a broad concept that has been used widely over a long time, being given many shades of meaning. It means the emotional and physical expressions in a human being with respect to gender differentiation. Sexuality is a strong biological drive at the same level as the drive to eat, drink, sleep, rest, etc. Human sexuality plays a role

sexual identities which in contemporary society are asking to be recognized as they are.

11 The text does not indicate the marital status of the two; only implying that illicit sex was involved. 
in the formation of personality as to who a person is or will become, being able to influence how a person experiences himself or herself as an individual member of society. It is not farfetched to say that the biological component is a distinctive determinant in human sexuality.

Human sexuality is about being male or female. That being the case, then what follows naturally is the justification of the presence of the biological inclination of attraction to a male or to a female. It, therefore, goes without saying that the ideal is for a man to partner with a woman and vice versa. The fact is that where an adult is unmarried, it implies he or she defies the ideal. The marvel is that people who live single lives must be having alternative methods of managing their human sexuality needs. It cannot be expected that if someone is living a single life, then the natural human sexuality drive ceases to exist. The natural drive and desire are still there; in fact, if anything, it could be more insistent and unrelenting.

In traditional African society as well as in Christian teaching, there are specific confines within which men and women enjoy their sexuality. That confine is found within the marriage institution, which itself is a specifically controlled vocation regulated by commonly agreed customs, traditions and practices. As a component of human existence, sexuality influences and is influenced by culture, society, politics, philosophy, ethics and religion, among others. One other significant component of human sexuality concerns the natural inclination inherent in a man or woman. According to Christian teaching, human sexuality is God's creation and is designed to be enjoyed within a marital union. The union that is contemplated in the Bible is that between a man and a woman, namely people of opposite sexes.

In contemporary society, it seems to be the case that more and more people of marriageable age and beyond are single for whatever reasons they have.

\footnotetext{
${ }^{12}$ At the present time there are adults who have chosen not to marry or remarry; who wish to enjoy life at their own terms. See Elyakim Kislev. Happy Singlehood: The Rising Acceptance and Celebration of Solo Living. University of California Press, 2019.

${ }^{13}$ See Peter J. Stein. "Singlehood: An Alternative to Marriage," in The Family Coordinator vol 24, No. 4 (Oct. 1975) pp.489503.
}

In the church today, there is a large number of young men aged thirty years old and above who are not married and yet do not have immediate plans to marry. ${ }^{12}$ There is a similar, if not a bigger number of women in the same category. At the present time, marriage does not seem to be a priority to young adults. ${ }^{13}$ How much times have changed? Be that as it may, it is reasonable to think that, however, the times have changed in respect to attraction to marriage, it is possible to say that matters about human sexuality have not changed in the same magnitude. In fact, if anything, the contemporary society is fixated on sex to the extent that none fails to notice the obsession. It is strange that even if there is that lavish emphasis and exposure to matters concerning sexuality in the society, more and more people are opting to lead single lives without the companionship of a person of the opposite gender. There are some celebrities who have made it public that they have opted to living single lives. This is a recent trend which is becoming popular among rich, professional and famous young people who prefer to be categorized as 'socialite.' The new trend goes by the name of sologamy; also known as selfmarriage which is a practice where a person marries oneself. ${ }^{14}$

\section{MEMOIRS OF SINGLE WOMEN IN THE CHURCH}

In traditional society's customary expectations require that a daughter of marriageable age should start a new life with her husband. ${ }^{15}$ Further, the daughter is not expected to inherit anything at her parental home. Because of that cultural specification, at the present time, many women after attaining the age of marriage, leave their home in the village to go and reside in rental accommodation in urban centres or at the village market where they occupy rooms at the back of shops and other business premises. A typical example of this

\footnotetext{
${ }^{14}$ Sologamy is a contemporary form of 'marriage' where a person 'marries' oneself, meant to demonstrate love to self. The trend is popular among young and famous celebrities who claim they have promised to honour, cherish, respect and done something special to themselves.

15 See Tabitha Kanogo. African Womanhood in Colonial Kenya. Nairobi: East African Educational Publishers, 2005.
} 
arrangement is that of Kemunto, whose predicament is narrated elsewhere in the discussion.

The single woman who leaves her parental home to seek shelter elsewhere is oftentimes not economically self-sustaining. Customary laws do not allow the woman access to tools of economic empowerment. Notice for instance, that she is not included in the parental inheritance. In the paper 'Sexuality in Culture and Law,' Tabitha Kanogo observes that traditional and cultural restrictions are things that continue to disadvantage women, especially those who are single. ${ }^{16}$ Traditional customs do not allow an unmarried woman flexibility and freedom to navigate through social and economic life as they are viewed as a threat to married families, bad role models to younger women and a disgrace to the institution of marriage.

During the late nineteen nineties, two women writers published a book with a captivating title. Sue Headlee and Margery Elfin wrote The Cost of Being Female, 1996. The conceptual framework of the book contends that it is expensive to be female. According to the authors, society is unashamedly male-oriented to the extent that it costs a woman more to navigate through the living experience than it does a male. ${ }^{17}$ According to Headlee and Elfin, a female, especially a single one, faces difficulties in navigating through life because she experiences undue bias in many areas of the living experience making her feel like she is a social pariah. Headlee and Elfin claim that because of gender differentiation and patriarchy when a woman begins to fend for herself, that becomes the moment the cost of being female turns out to be psychologically and actually high. ${ }^{18}$ What this means is that in a society that is widely male-oriented, a woman who is the head of a household finds herself on the unfamiliar side of the living experience.

The phenomenon of singlehood and singlemotherhood for that matter is not necessarily new.

\footnotetext{
${ }^{16}$ Ibid.

${ }^{17}$ Sue Headlee and Margery Elfin. The Cost of Being Female. Westport, Connecticut, 1996, p.47.

18

Ibid., p.54.

19 Lynn M. Thomas. Politics of the womb: Women, Reproduction and the State in Kenya. University of California Press, p. 135.
}

It goes back many years in history, indicating that the phenomenon is in fact, part of life. In research about women and reproductive health in Kenya, Lynn M. Thomas observes that single motherhood is a growing trend but that it is not necessarily a new thing. ${ }^{19}$ What should the response of the church to the increasing number of single and unattached women in its ranks? It is imaginable that single women actually influence the commitment of men to their marriages? Should the Christian church in Africa rethink the teaching about polygamy as a measure to mitigate the number of single and unattached women in its ranks? The opinion imagines that if Christian teaching were allowing polygamy, there would be fewer unattached women in the church as many of them would be absorbed into polygamous marriages.

Some thirty years ago, David Mailu a Kenyan author and social critic, wrote a book that was received with a measure of apprehension because it was perceived as dabbling in the embarrassing territory. The book; Our Kind of Polygamy deals with contemporary relationships where men and women are in monogamous marriages but who still engage in plural sexual relationships. ${ }^{20}$ One of the reasons which Mailu identifies is that more and more women are unattached and are readily available and are willing to connect to both married and unmarried men.

In contemporary society, the animal called modernity is 'gnawing' ferociously at the traditional customs, traditions and practices. ${ }^{21}$ Traditionally, it is customary for plural marriages to occur; namely, a man is 'allowed' to marry more than one wife, meaning the women in the marriage are culturally socialized to match up to the practice where a woman is one of many wives in the marriage. By extension, the culture makes it possible for many women to be attached to one man, leaving fewer women staying unattached. A young man of marriageable age is ordinarily under pressure to

\footnotetext{
${ }^{20}$ David G. Mailu. Our Kind of Polygamy. Nairobi: Heinemann 1988, p.168. In an earlier book which came out in 1971 titled After 4.30, Mailu had published material which was criticized because it was regarded as sexually explicit

${ }^{21}$ Kilbride and Kilbride, p.ix.
}

33 This work is licensed under a Creative Commons Attribution 4.0 International License. 
marry such that rarely does a man experience his life without a woman in his life. For women, the culture is not kind because a woman expects a man to come to propose marriage to her. Culturally she is not supposed to propose marriage to a man, meaning that the expectation keeps a young woman single as long as a man has not approached her with a proposal.

Christian culture teaches that a man can only marry one wife at a time unlike the traditional culture which allows a man to marry more than one wife. What the Christian teaching has in effect done is that because a man can only marry one wife, there are many women who remain unattached, experiencing life without a man to whom she is officially attached to. ${ }^{22}$ There are a number of questions that come to the fore, such as whether or not the Christian culture is the source of the increasing number of single women in the church. One wonders whether it would be conceivable to adjust the teaching so that more women can get absorbed in the marriage institution. Is the church shooting herself on the foot through its teaching of one man one wife? How is the single man or woman supposed to deal with the unrelenting craving for human sexuality? Is it possible that the teaching about sex outside the marital union could be adjusted to allow single people freedom to manage their sexuality? These are questions whose answers cannot be expected to be immediately forthcoming.

\section{CONCLUDING REMARKS}

The discussion has examined the phenomenon of singlehood as a category found in society and by extension in the church. The singles are both male and female. Singlehood is identified as a phenomenon that impacts the church polity to a large extent. It is stated herein that single men impact the sexual lives of single and married females as well as single females impact the lives of single and married males.

The reason why there is an increasing rate of singlehood is not given. For the case of females, the increase may possibly be the result of female sexual

\footnotetext{
${ }^{22}$ The Christian practice relates poorly with the demographical reality which ordinarily says there are more females than males in any society.
}

emancipation because as single, a woman has the flexibility to negotiate her sexuality unlike in marriage where her husband is the one in charge. This discussion entertains the view that single women in the society seriously question the cultural perceptions of female sexuality. It is observed herein that women are in some circles regarded as tempters of men. The perception may not be entirely accurate either nor unfounded. Incidents where young women have led highly placed men in public and in the church to fall from grace, including not so long ago the case of a prominent American politician and recently a distinguished member of a famous royal family are within living memory. ${ }^{23}$

The Bible speaks candidly on various aspects of human sexuality. Sex is part of God's creation meant to be enjoyed within marriage. Biblical prescription condemns pre-marital and extramarital expressions of human sexuality. Possibly the Bible does not foresee the possibility of one not ever getting married and therefore does not make provision for the single man and woman. The issue that has been discussed raises the question about the single adult who by all means goes through natural emotions originating from one's human sexuality. How is human sexuality meant to find fulfilment in the life of a single adult?

Take for instance the case of a woman who finds herself single by choice or by default. By being single means that the woman is the head of a household. She is thereby expected to secure food, shelter and clothing. If she has children, then she is expected to cater for their needs. As if that is not enough, a single woman has to deal with negative social sentiments which discredit singlehood. The sentiments are not always complimentary. Then there is the pressure from children wanting to know who their father is. Peers who are married contribute their share of pressure bullying the single adult either to marry or perceiving them as a threat to their marriages.

A single woman may think that she will find comfort and contentment in the church. But that quickly proves her wrong because in some cases, that is the time when her tribulations begin. An

23 During the period 1995 -1997 a high-ranking American politician was roped into a sex scandal which in part involved singlehood. 
unattached woman is an insecure person in the midst of the congregation, probably giving a reason as to why singlehood has a wide-ranging impact on the church. A single woman for instance, impacts the married men and women, youth and fellow single women. To the married men, she may be having affairs with the men in the church. To the married women, the single woman might be perceived as a tempter of husbands and to the youth she is not a respectable role model. The phenomenon of singlehood is undoubtedly a pressing challenge that is relentlessly demanding to be addressed. The way the present-day church will respond will determine the character of the church for many years to come 